Luchyk Vasyl, Doctor of Sciences (Economics), Full Professor, Chernivtsi Institute of Trade and Economics Kyiv National University of Trade and Economics, Chernivtsi, Ukraine ORCID 0000-0002-1997-0272, Researcher ID P-2946-2016 Koroliuk Yurii, Doctor of Sciences in Public Administration, Associate Prof., Chernivtsi Institute of Trade and Economics Kyiv National University of Trade and Economics, Chernivtsi, Ukraine ORCID 0000-0001-8732-3731, Researcher ID P-2899-2016

\title{
FUZZY LOGIC MODELING OF REGIONAL ECONOMY DEVELOPMENT SCENARIOS
}

In the present paper there is shown the application of the Fuzzy modeling method in solving the problem of scenario forecasting of regional development, based on the analysis coordination of the expert evaluation data and the data of regional statistics. A two-hierarchical fuzzy model with four input parameters, describing the development of Chernivtsi region, two intermediate and one output parameter were built in Matlab2017b. The model included a set of 27 fuzzy rules and used the Mamdani method for fuzzy decision-making and fuzzy inference. Defuzzification was performed using the Center of Gravity method. Analysis of the regional statistics selected data of Chernivtsi region confirmed the adequacy and prospects of using the model. In particular, there has been identified the need to reduce significantly the unemployment rate to reach the threshold of the optimistic scenario development.

Keywords: regional development, scenario forecasting, Fuzzy logic, Fuzzy set.

\section{Лучик Василь, Королюк Юрій. Нечітке моделювання сценаріїв} розвитку регіональної економіки.

У роботі описано застосування методу нечіткого моделювання при вирішенні проблеми прогнозування сиенарію регіонального розвитку. Дослідження реалізовано на основі аналізу координації даних експертної оцінки та даних регіональної статистики. Двоєєрархічна нечітка модель була побудована в Matlab2017b і містила чотири вхідні параметри, що описують розвиток Чернівецької області, два проміжні та один вихідний параметр. Модель 
включала набір з 27 нечітких правил і використовувала метод Мамдані для нечіткого прийняттяя рішень і нечіткого висновку. Дефузіфікація проводилась методом Центру мас. Аналіз регіональних статистичних показників Чернівецької області підтвердив адекватність та перспективи використання моделі. Зокрема, виявлено необхідність суттєво знизити рівень безробіття, щоб досягти межі розвитку оптимістичного сценарію.

Ключові слова: регіональний розвиток, сценарне прогнозування, нечітка логіка, нечітка множина.

Relevance of research topic. In Ukraine the regional economic development is characterized by a considerable inter-regional differentiation, so regional development policy should be based on the implementation of systematic regional forecasts, differentiated by directions, industries and terms. When setting and carrying out national tasks, the territorial aspect must be indispensably considered and not only national but also regional priorities must be taken into account. Ukraine, on its path to forming a highly developed economy and social sphere, needs mechanisms that can offer alternatives of such development. Being able to obtain the development scenarios in optimistic and pessimistic planes will allow the government to elaborate management decisions better and more objectively.

Thus, today there is urgent the need for scientifically substantiated local expert views agreement and the available statistical base of regional indices with the tendency to objective forecasts formation as to the development of Ukrainian regions.

Formulation of the problem. The system of measures for the regional development policy implementation is based on the assessment, quality forecasting and programming of the regions' development, the main purpose of which is to determine the priorities of regional development, to maximize the use of competitive advantages and minimize the negative factors influence, as well as to harmonize national, regional and local interests.

Analysis of recent researches and publications. According to L.I. Fedulov, regional forecasts are wrongly aimed at obtaining macroeconomic indices only, they should be of primary importance in setting strategic goals and components of public policy in a particular field of activity. In other words, regions should take into account the trends and challenges at all levels that affect their development [3, P. 95].

Modeling and forecasting is now at a fundamentally new stage of its development. It is impossible to obtain accurate forecasts for solving increasingly complex tasks facing our country without mastering the resources of the so-called information society. The information itself is insufficient for forecasting and proper decision making, so it is necessary to master modern methods of its analysis and processing.

One of the main techniques for implementing systematic research on complex developing objects is scenario forecasting. This definition lies in the basis of forming a comprehensive procedure for conducting a complex scenario study of the forecasting 
object. Carrying out a scenario study is a kind of filling with content that is real, and peculiar only for this object of study. The whole set of procedures in this approach is based on the combination of meaningful logical-heuristic approach with formal methods of systems research, first of all by means of economic and mathematical modeling. As a rule, externally they are organized as interactive procedures that mean involving the intelligence of researchers at one evaluation stage or another. A feature of this forecast tool is its rigid orientation on the forecasting objective. It is because they allow to distinguish the system under study out of the overall picture of a realfunctioning environment, make a list of relationships, dependencies, indicators, parameters essential for the study, evaluate functional, technological and pragmatic applicability of certain mathematical methods as the means of describing and studying the properties of the research object.

In the general case, the purpose of the scenario forecast developing can be reduced to three basic situations or their different combinations:

observing the system development under different hypotheses regarding the mechanism of this development formation;

identification of critical situations, 'bottlenecks' in the development of the system;

development and assessment of effective strategies for future development problem solving.

The first two objectives of the study correspond to the passive function of the forecast, the latter reflects its active component. Thus, like any method of scientific cognition, scenario forecasting realizes all the basic functions of scientific research: descriptive, explanatory and prognosing.

In general, creating of scenarios is aimed at solving two main problems, namely: highlighting the key moments of development of the research object and developing on this basis qualitatively different variants of its dynamics; comprehensive analysis and evaluation of each of the options obtained, studying its structural features and possible consequences of its implementation.

Thus, the scenario is always considered in dynamics, that is, when developing the «history» of the object under study in time and / or space. Therefore, in the scenario space, an individual scenario is not a point, but a vector or a trajectory, which shows the change of the system characteristics in the course of a given series of iterations.

The method of scenario forecasting at the present stage, as a rule, uses two main methods: Delphi and Foresight.

The essence of the Delphi method, which was proposed in 1963 by T.G. Gordon, O. Helmer [5], is a summary and statistical analysis of specialists in each industry on the prospects of the development of this and the related industries. Its main purpose is to discover new ideas based on intuitive reflections in the process of considering individual phenomena from different points of view. It is based on the hypothesis that many ideas contain some good ideas. And the problem is to find those good ones. 
The Foresight method is quite effective in solving the forecasting problem for objects that can influence actively the environment and have the ability to change their location to achieve future desired states. These features are met by economic objects of all levels of complexity because they are created in the process of purposeful activity and at the same time are subject to uncertainty and risk [4].

System of Foresight methods is constantly developing and improving, with extensive experience of their applied use. At the same time, it is becoming apparent that major national projects for selecting priority ways of developing the country require new approaches that would provide objective assessment. In this sense, the idea of the Foresight Triangle, whose vertices represent the key factors that provide the result of working with experts, was improved: creativity, expertise and interaction [6].

In their works I. Miles and R. Popper suggested to add another vertex - the proof [7]. In this way, the triangle became a rhombus, which made it possible to forecast the development of advanced technologies, the construction of long-term scenarios for the development of many technological industries, the solution of social and economic problems, etc more effectively.

Foresight is based on forecasting the options for a possible future, which may come under certain conditions: the correct determining the development scenarios, reaching consensus when choosing a desired scenario, taking steps in its implementation. There are many forecasting methods, but Foresight programs use only 10-15 of them the most intensively: Delphi method, critical technologies, scenario development, technology roadmap and expert panel formation, etc.

Foresight technology, based on the Delphi method has been the most popular in recent years. The method is based on the interviewing a large number of experts. It is used in Japan, Germany, the United Kingdom, etc. The method requires the creation of expert panels in particular fields of science and technology; developing a list of topics potentially scientific and technological achievements, which are expected in the long term up to $25-30$ years.

Thus, expert review enhances substantially the potential for the applied use of scenario forecasting methods. Experts are able to take into account the complex dynamics of regional development in real time, to make necessary adjustments to the offered solutions, to reach agreement in the case of many forecasting factors. However, having an expert review leads to subjectivity and imprecise decisions. Forecasting models based on expert opinion cannot fully rely on deterministic mathematical methods. Also, the objective insufficient number of experts and their assessment precludes the use of probabilistic forecasting methods.

It is suggested to use fuzzy logic methods to solve the above problems. Fuzzy logic theory was offered by Zadeh in the middle of the last century. The main advantages of the theory are the ability to model uncertainty, to describe subjective statements of human knowledge and experience [8], to turn fuzzy information into clear one with further mathematical processing and linguistic output of results. In regional government, fuzzy logic methods are actively used to solve problems of 
regional development assessment [9], development planning [1], assessment of local sustainability [2], and many others.

However, the diversity and uniqueness of regional systems and their environment requires a certain approach to solving forecasting problems, including using fuzzy logic methods.

So, the objective of the article is to build and test a forecasting model for assessing regional development scenarios using fuzzy logic methods.

Presenting main material. Indices of the Chernivtsi region development for 2014-2017 were chosen as the object of research. The system of national accounts quite broadly and accurately parameterizes the state of the regional socio-economic system of Chernivtsi region. In particular, more than a few hundred monthly, quarterly and annual statistic indices are expected to be input. On one hand, this fact contributes to the comprehensive disclosure of the region development process. On the other hand, the final assessment of its condition is challenging. Different statistic methods are used to solve the problem, including integral assessment, cluster analysis, different averaging, etc. However, the results of such methods application are often controversial in the case of comparisons. The prospect of resolving this is the attempt to apply expert judgment as analyzed by fuzzy logic methods.

Parameterization of the research object involved the selection of indices that describe the region's development state most significantly: gross regional product index (GRPI), industrial production index (IPI), agricultural production index (API), unemployment rate index (URI). The indices values were taken from the official data of the State Statistics Service of Ukraine. These parameters were indexed with the purpose of qualitative fuzzification. The model parameter fuzzification was performed with the help of three linguistic variables («pessimistic», «stagnant», «optimistic») by the triangular membership function (see Table 1).

Setting the membership functions was accomplished by the Fuzzy Tool Box of Matlab2017b environment. Figure 1 shows an example of the GRPI parameter membership function.

Table 1

\section{Fuzzy set of the model}

\begin{tabular}{|l|l|l|l|l|}
\hline \multicolumn{1}{|c|}{ Variable } & \multicolumn{1}{c|}{$\begin{array}{c}\text { Type of } \\
\text { variable }\end{array}$} & Linguistic term & $\begin{array}{c}\text { Membership } \\
\text { function }\end{array}$ & \multicolumn{1}{|c|}{ Interval } \\
\hline \multirow{3}{*}{ GRPI, IPI, API, URI } & \multirow{2}{*}{ input } & pessimistic & triangular & $(70,70,100)$ \\
\cline { 3 - 5 } & & stagnant & triangular & $(80,100,130)$ \\
\cline { 3 - 5 } & \multirow{3}{*}{ output1, output2 } & optimistic & triangular & $(100,140,140)$ \\
\hline \multirow{3}{*}{ output3 } & pessimistic & triangular & $(100,140,140)$ \\
\cline { 3 - 5 } & \multirow{3}{*}{ output } & stagnant & triangular & $(0.25,0.5,0.75)$ \\
\cline { 3 - 5 } & & optimistic & triangular & $(0.5,0,75,1,1)$ \\
\hline & pessimistic & triangular & $(0,0,0.4)$ \\
\cline { 3 - 5 } & stagnant & triangular & $(0.1,0.5,0.9)$ \\
\cline { 3 - 5 } & optimistic & triangular & $(0.6,1,1)$ \\
\hline
\end{tabular}




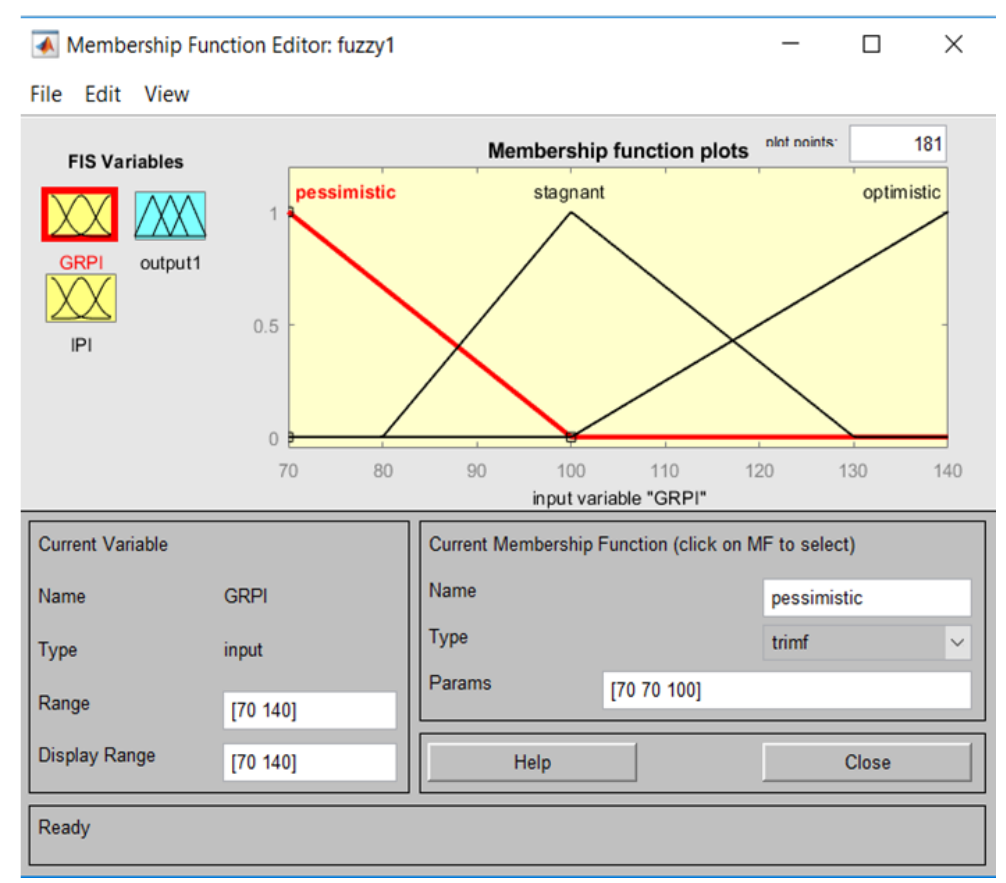

Figure 1. An example of setting the membership functions of the GRPI input parameter

The boundaries of the universal set were determined taking into account the behavior of the research parameters over the last 4 years. The names and shapes of membership functions were chosen taking into account the approaches of expert review to regional development scenarios.

The fuzzy model was built in the Simulink Matlab2017b environment. To simplify the formation of the set of fuzzy rules, the model was formed in a twohierarchical form (see Figure 2).

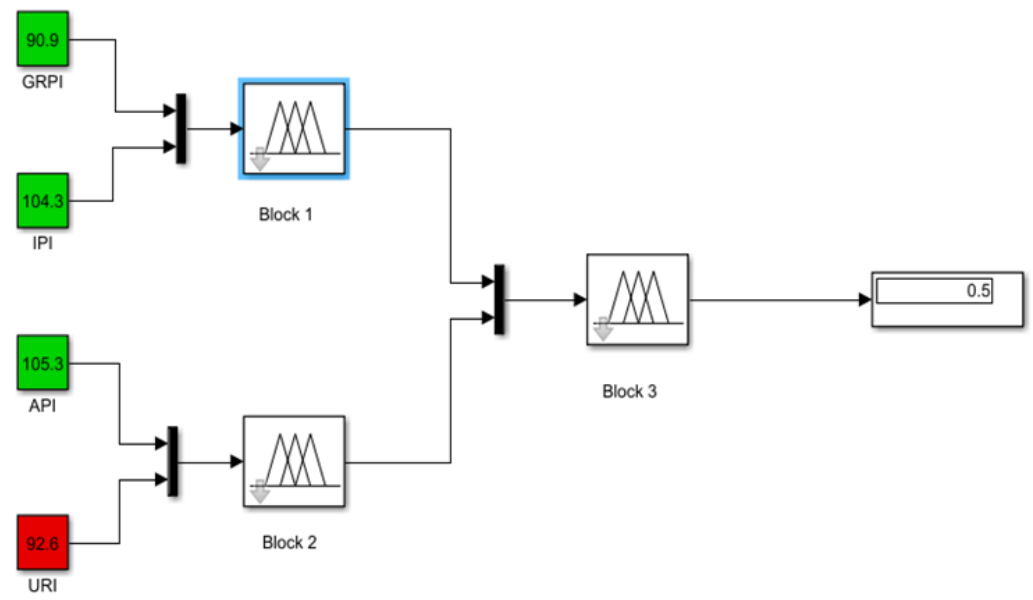

Figure 2. Two-hierarchical fuzzy model in Simulink (Matlab) environment

The set of 27 fuzzy rules for all three fuzzy blocks of the model is shown in Table 2. The set of fuzzy rules is also formed and specified by expert review, extending the universality of the model application in the case of other regions as well. 


\section{Set of rules}

\begin{tabular}{|c|c|c|c|c|}
\hline & IF & & THE & \\
\hline \multirow{10}{*}{ Block 1} & GRPI & IPI & wf & Output 1 \\
\hline & pessimistic & pessimistic & 1.00 & pessimistic \\
\hline & pessimistic & stagnant & 1.00 & pessimistic \\
\hline & pessimistic & optimistic & 1.00 & stagnant \\
\hline & stagnant & pessimistic & 1.00 & stagnant \\
\hline & stagnant & stagnant & 1.00 & stagnant \\
\hline & stagnant & optimistic & 1.00 & stagnant \\
\hline & optimistic & pessimistic & 1.00 & stagnant \\
\hline & optimistic & stagnant & 1.00 & optimistic \\
\hline & optimistic & optimistic & 1.00 & optimistic \\
\hline \multirow{10}{*}{ Block 2} & API & URI & DoS & Output 2 \\
\hline & pessimistic & pessimistic & 1.00 & stagnant \\
\hline & pessimistic & stagnant & 1.00 & stagnant \\
\hline & pessimistic & optimistic & 1.00 & pessimistic \\
\hline & stagnant & pessimistic & 1.00 & optimistic \\
\hline & stagnant & stagnant & 1.00 & stagnant \\
\hline & stagnant & optimistic & 1.00 & pessimistic \\
\hline & optimistic & pessimistic & 1.00 & optimistic \\
\hline & optimistic & stagnant & 1.00 & stagnant \\
\hline & optimistic & optimistic & 1.00 & stagnant \\
\hline \multirow{10}{*}{ Block 3} & Output 1 & Output 2 & DoS & Output 3 \\
\hline & pessimistic & pessimistic & 1.00 & pessimistic \\
\hline & pessimistic & stagnant & 1.00 & pessimistic \\
\hline & pessimistic & optimistic & 1.00 & stagnant \\
\hline & stagnant & pessimistic & 1.00 & pessimistic \\
\hline & stagnant & stagnant & 1.00 & stagnant \\
\hline & stagnant & optimistic & 1.00 & optimistic \\
\hline & optimistic & pessimistic & 1.00 & stagnant \\
\hline & optimistic & stagnant & 1.00 & optimistic \\
\hline & optimistic & optimistic & 1.00 & optimistic \\
\hline
\end{tabular}

When forming the set of rules, it was taken into account that the GRPI parameter has a significant impact on the regional development assessment, and the increase of the URI parameter is negative in the same assessment. Weighting factor (wf) for all rules was taken as 1 .

Mamdami method was used for fuzzy decision-making and fuzzy inference. Output defuzzification was performed on the basis of the membership functions of Table 1 and the Center of Gravity method. Figure 3 shows an example of an intermediate defuzzification of the output parameter 1 .

The model was tested on the basis of analysis of Chernivtsi region data indices for 2014-2017 (see Table 3). 
The results of the work confirm the stagnant state of Chernivtsi region development for the research period. The clear index of the model's output defuzzificated parameter was in the range $0.4979-0.5265$, which corresponded to the value of the «stagnant» linguistic variable (Table 3 ).

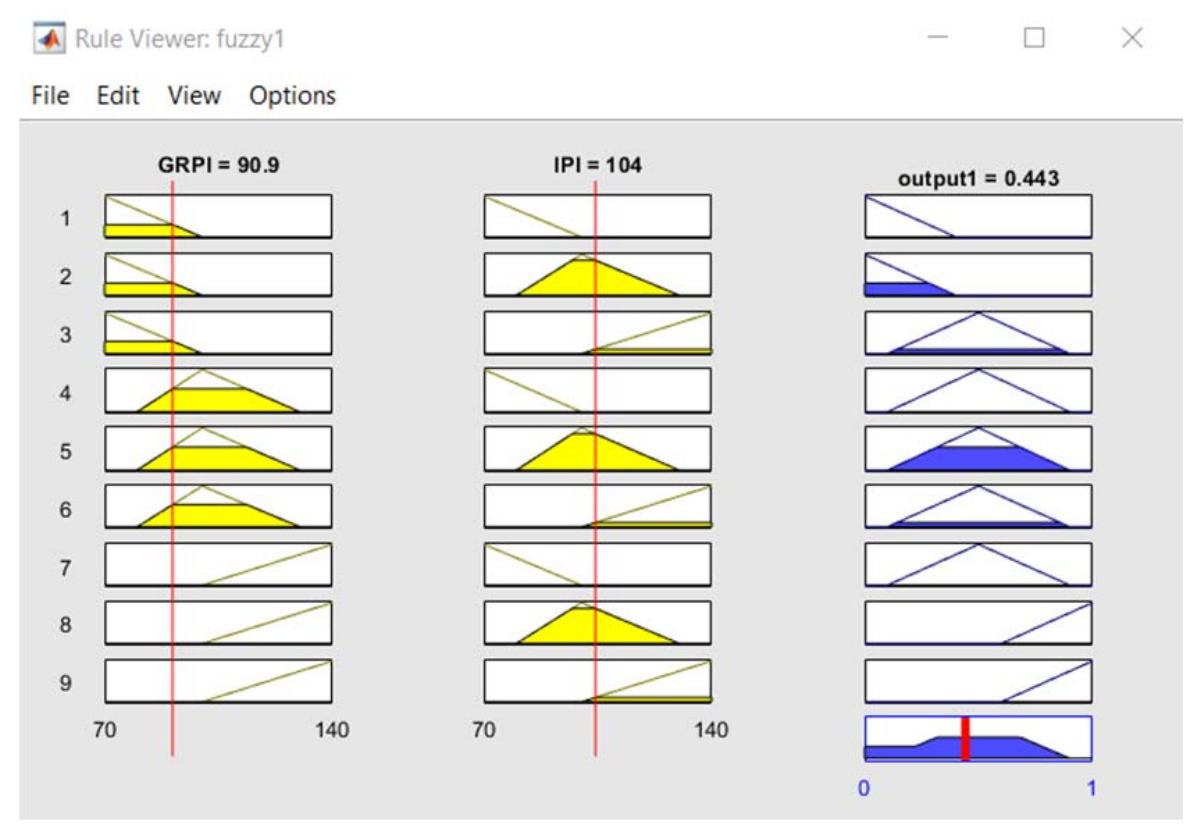

Figure 3. An example of output parameter 1 defuzzification

Table 3

Assessment of the state and development scenarios of Chernivtsi region

\begin{tabular}{|l|l|l|l|l|l|}
\hline Years & \multicolumn{1}{|c|}{$\begin{array}{c}\text { Gross } \\
\text { regional } \\
\text { product index } \\
\text { (GRPI) }\end{array}$} & $\begin{array}{c}\text { Industrial } \\
\text { produ-ction } \\
\text { index (IPI) }\end{array}$ & $\begin{array}{c}\text { Agricultu-ral } \\
\text { production } \\
\text { index (API) }\end{array}$ & $\begin{array}{c}\text { Unemploy- } \\
\text { ment rate } \\
\text { index (URI) }\end{array}$ & Output 1 \\
\hline 2014 & 109.2 & 92.9 & 104.2 & 118.6 & 0.4979 (stagnant) \\
\hline 2015 & 122.9 & 98.3 & 91.1 & 102.9 & 0.5265 (stagnant) \\
\hline 2016 & 114.9 & 96.7 & 100.0 & 90.5 & 0.5 (stagnant) \\
\hline 2017 & 90.9 & 104.3 & 105.3 & 92.6 & 0.5 (stagnant) \\
\hline Scenario 1 & 120.0 & 110.0 & 110.0 & 80.0 & 0.75 (optimistic) \\
\hline Scenario 2 & 140.0 & 125.0 & 125.0 & 90.0 & 0.75 (optimistic) \\
\hline
\end{tabular}

Two model scenarios (Scenario 1 and Scenario 2 Table 3) were analyzed to study the contribution of input parameters to the development state of the region. The modeling showed that in order to obtain an optimistic development scenario (in our case the output index should be greater than 0.75), Chernivtsi region needs to achieve high rates of GRPI, IPI, API. But even under such conditions, a high unemployment rate significantly lowers the initial assessment of the development. For the scenarios under study, the unemployment rate should be reduced to at least 80 and 90 indices respectively (Table 3 ). Such results confirm that the development of Chernivtsi region 
economy in the context of high unemployment and significant labor outflow is impossible even with significant innovation and capital investment.

Conclusion. Forecasting assessment of the region's economy development scenarios is a complex process with the tendencies of attracting experienced experts as the greatest applied potential. However, the subjective and unclear nature of expert review makes the use of deterministic and probabilistic methods of analysis impossible. Fuzzy modeling method was tested in this paper to solve this problem.

In the Matlab2017b environment there was constructed a two-hierarchical fuzzy model with four input parameters describing the state of Chernivtsi region development by two intermediate parameters and an output one. The model had a set of 27 fuzzy rules and used the Mamdani method for fuzzy decision-making and fuzzy inference. Defuzzification was performed using the Center of Gravity method.

The analysis of the regional statistics selected data of Chernivtsi region confirmed the adequacy and prospects of application the offered model. In particular, there has been ascertained the need to reduce significantly the unemployment rate to reach the threshold of the optimistic development scenario.

\section{REFERENCES}

1. Bick, I. A., Bardhan, R., \& Beaubois, T. (2018) Applying fuzzy logic to open data for sustainable development decision-making: A case study of the planned city Amaravati.. Natural Hazards, 91(3), pp 1317-1339.

2. Canavese, D., Ortega, N. R. S., \& Queirós, M. (2014) The assessment of local sustainability using fuzzy logic: An expert opinion system to evaluate environmental sanitation in the Algarve region, Portugal. Ecological Indicators, 36, P. 711-718.

3. Fedulov, L.I. (2008) Forsight: a modern methodology for technical forecasting. Ekonomika i prohnozuvannia, 3, pp. 106-120. [in Ukrainian]

4. Fysher S., Dornbush R., Shmalenzy R. (2002) Economics, M.: Delo. 864 p. [in Russian].

5. Gordon T., Helmer (1964) O. Report on a Long Range Forecasting Study. RAND Paper P-2982. RAND Corporation, Santa Monica, California, $163 \mathrm{p}$.

6. Loveridge D. (2001) Foresight. PREST. University of Manchester. $200 \mathrm{p}$.

7. Popper R. (2007) Methodology: Common Foresight Practices \& Tools, in Georghiou, L. et al., International Handbook on Foresight and Science Policy: Theory and Practice. Edward Elgar. - pp.44-68.

8. Zadeh, L.A. (2008). Is there a need for fuzzy logic? Information Sciences 178 (13), P. 2751-2779.

9. Zhalezka B., (2015). Navitskaya K. Multy-criteria fuzzy analysis of regional development, ECONTECHMOD. An international quarterly journal, 4(3), P. 39-46. 